\title{
Iron as the Key Modulator of Hepcidin Expression in Erythroid Antibody-Mediated Hypoplasia
}

\author{
J. C. Fernandes, ${ }^{1,2}$ P. Garrido, ${ }^{1}$ S. Ribeiro, ${ }^{2,3}$ P. Rocha-Pereira, ${ }^{2,4}$ E. Bronze-da-Rocha, ${ }^{2,3}$ \\ L. Belo, ${ }^{2,3}$ E. Costa, ${ }^{2,3}$ F. Reis, ${ }^{1}$ and A. Santos-Silva ${ }^{2,3}$ \\ ${ }^{1}$ Laboratory of Pharmacology and Experimental Therapeutics, IBILI, Faculty of Medicine, University of Coimbra, \\ 3000-548 Coimbra, Portugal \\ ${ }^{2}$ Institute for Molecular and Cellular Biology, University of Porto, 4150-180 Porto, Portugal \\ ${ }^{3}$ Department of Biological Sciences, Faculty of Pharmacy, University of Porto, Rua de Jorge Viterbo Ferreira No. 228, \\ 4050-313 Porto, Portugal \\ ${ }^{4}$ Research Centre in Health Sciences, University of Beira Interior, 6201-001 Covilhã, Portugal \\ Correspondence should be addressed to A. Santos-Silva; assilva@ff.up.pt
}

Received 23 June 2014; Accepted 12 October 2014; Published 18 December 2014

Academic Editor: Beatrice Charreau

Copyright (C) 2014 J. C. Fernandes et al. This is an open access article distributed under the Creative Commons Attribution License, which permits unrestricted use, distribution, and reproduction in any medium, provided the original work is properly cited.

\begin{abstract}
Erythroid hypoplasia $(\mathrm{EH})$ is a rare complication associated with recombinant human erythropoietin (rHuEPO) therapies, due to development of anti-rHuEPO antibodies; however, the underlying mechanisms remain poorly clarified. Our aim was to manage a rat model of antibody-mediated $\mathrm{EH}$ induced by rHuEPO and study the impact on iron metabolism and erythropoiesis. Wistar rats treated during 9 weeks with a high rHuEPO dose (200 IU) developed $\mathrm{EH}$, as shown by anemia, reduced erythroblasts, reticulocytopenia, and plasmatic anti-rHuEPO antibodies. Serum iron was increased and associated with mRNA overexpression of hepatic hepcidin and other iron regulatory mediators and downregulation of matriptase-2; overexpression of divalent metal transporter 1 and ferroportin was observed in duodenum and liver. Decreased EPO expression was observed in kidney and liver, while EPO receptor was overexpressed in liver. Endogenous EPO levels were normal, suggesting that anti-rHuEPO antibodies blunted EPO function. Our results suggest that anti-rHuEPO antibodies inhibit erythropoiesis causing anemia. This leads to a serum iron increase, which seems to stimulate hepcidin expression despite no evidence of inflammation, thus suggesting iron as the key modulator of hepcidin synthesis. These findings might contribute to improving new therapeutic strategies against $\mathrm{rHuEPO}$ resistance and/or development of antibody-mediated $\mathrm{EH}$ in patients under rHuEPO therapy.
\end{abstract}

\section{Introduction}

Erythropoietin (EPO), a $30.4 \mathrm{kDa}$ glycoprotein, is a key hormone in the regulation of erythropoiesis, supporting proliferation, survival, and terminal differentiation of erythroid progenitor cells in the bone marrow [1,2]. These effects are mediated through the interaction of EPO with its specific transmembrane receptor-erythropoietin receptor (EPOR) [3]. Acquired EPO deficiency has been associated with chronic kidney disease (CKD) and with chronic inflammatory diseases. Treatment with recombinant human erythropoietin (rHuEPO) achieves correction of these types of anemia; however, $5-10 \%$ of CKD patients develop resistance to the erythropoietic stimuli of rHuEPO. Several factors have been proposed to play a role in the development of this resistance, but the etiology of the impaired erythropoiesis, leading to worsening of the anemia or even to pure red cell aplasia (PRCA), is still unknown [4]. Casadevall et al. (1996) reported the presence of anti-EPO antibodies in a patient with transient PRCA, which functionally blocked the interaction between EPO and EPOR, thus resulting in impaired erythropoiesis [5]. Hara et al. (2008) also reported that serum from a patient with PRCA inhibited EPOdependent cell proliferation, suggesting that the anemia was mediated by anti-EPO antibodies [6]. In several other cases, antibodies have been described in PRCA patients' sera that were selectively cytotoxic for marrow erythroid cells or were directed against EPO [7-9]. 
The current therapeutic use of rHuEPO to correct anemia in CKD patients has been associated with some cases of PRCA, due to the development of cross-reactive anti-EPO antibodies $[10,11]$. Although this complication is very rare, the mechanisms underlying the break in immune tolerance to $\mathrm{rHuEPO}$ remain poorly clarified. The development of PRCA should be suspected in patients who have been under rHuEPO therapy for more than 3 months and develop a sudden severe unexplained fall in hemoglobin levels and reticulocytopenia and a marked decrease in bone marrow erythroblasts, despite continuing with rHuEPO treatment [12]. The diagnosis is confirmed by low serum EPO levels and detection of anti-EPO antibodies [13]. The production of anti-EPO antibodies and the inhibition of EPO-dependent erythroid cells are important mechanisms that might lead to erythroid hypoplasia $(\mathrm{EH}) / \mathrm{PRCA}$. The reduction in functional EPO affects the proliferative state of bone marrow erythroid cells, which will trigger several changes in iron metabolism, such as in serum iron, transferrin, and ferritin levels, among others [14-16].

Considering the scarce data in literature about how, facing a PRCA condition mediated by anti-EPO antibodies, the depression of marrow erythroid activity affects iron metabolism, our goal was to assess in male Wistar rats the effects of this condition on iron metabolism (iron absorption and iron traffic and storage) as well as on erythropoiesis. For that purpose, we performed hematological and biochemical studies to evaluate the erythropoietic and iron status and measured the expression of several mRNA-encoding erythropoiesis and iron metabolism regulating proteins on duodenum, liver, and kidney tissues.

\section{Material and Methods}

2.1. Animals and Experimental Protocol. Male Wistar rats (Charles River Lab. Inc., Barcelona, Spain), weighing 200$250 \mathrm{~g}$, were maintained in an air-conditioned room, subjected to $12 \mathrm{~h}$ dark/light cycles, and given standard laboratory rat diet (IPM-R20, Letica, Barcelona, Spain) without iron supplementation and free access to tap water. Animal experiments were conducted according to the European Communities Council Directives on Animal Care. These procedures were in accordance with the Association for Pharmacology and Experimental Therapeutics and were approved by the Institutional Ethics Committee of the Faculty of Medicine from the University of Coimbra, approval ID: FMUC/04/13. The rats were divided into 3 groups ( 8 rats each): control: treated with saline solution; 50 IU rHuEPO: a therapeutic dose of $50 \mathrm{IU} / \mathrm{Kg}$ body weight (bw)/week of epoetin beta (RecormonRoche Pharmaceuticals) treatment; 200 IU rHuEPO: treated with $200 \mathrm{IU} / \mathrm{Kg}$ bw/week of rHuEPO, a high dose, usually used on rHuEPO resistant patients. All the animals have completed the 9-week protocol (Figure 1).

\subsection{Sample Collection and Preparation}

2.2.1. Blood. At the beginning of the experiments $\left(T_{0}\right)$ and at $3\left(T_{1}\right), 6\left(T_{2}\right)$, and $9\left(T_{3}\right)$ weeks after the first rHuEpo

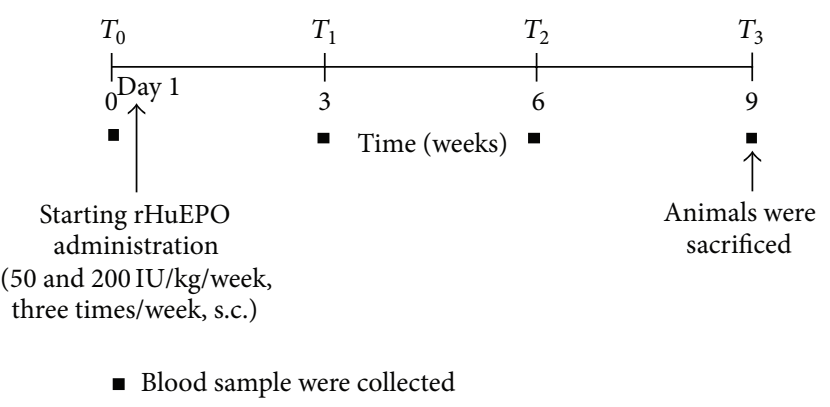

FIGURE 1: Experimental protocol.

dose, the rats were subjected to intraperitoneal anesthesia with a $2 \mathrm{mg} / \mathrm{kg}$ bw of a $2: 1$ (v:v) $50 \mathrm{mg} / \mathrm{mL}$ ketamine (Ketalar, Parke-Davis, Lab. Pfizer Lda, Seixal, Portugal) solution in 2.5\% chlorpromazine (Largactil, Rhône-Poulenc Rorer, Lab. Vitória, Amadora, Portugal). Blood samples were immediately collected by venipuncture, from the jugular vein, into vacutainer tubes without anticoagulant (to obtain serum) and with EDTA (to obtain whole blood and plasma) for hematological and biochemical studies; $3 \mathrm{~mL}$ blood samples were collected at $T_{0}, T_{1}$, and $T_{2}$ to minimize interference with erythropoiesis mechanism; at the end of protocol $\left(T_{3}\right)$, a $10 \mathrm{~mL}$ sample was collected in order to perform all the biochemical and hematological assays.

2.2.2. Tissues. At the end of the protocol, blood was collected and, afterwards, the rats were sacrificed by cervical dislocation; duodenum, liver, and kidneys were immediately removed, placed in ice-cold Krebs-Henseleit buffer, and carefully cleaned. A bone marrow aspirate from the femur was also performed.

2.3. Biochemical and Hematological Assays. Serum creatinine and urea concentrations were used as renal function indexes through automatic validated methods and equipment (Hitachi 717 analyser). Red blood cell (RBC), hematocrit, and hemoglobin $(\mathrm{Hb})$ concentration were assessed in whole blood EDTA by using an automatic Coulter Counter (Beckman Coulter Inc., CA, USA); reticulocyte (RET) count was performed by microscopic counting on blood smears after vital staining with New Methylene Blue (Reticulocyte Stain, Sigma-Aldrich, St. Louis, MO, USA). Serum levels of erythropoietin were evaluated by rat specific ELISA kit (MyBioSource, USA). Serum iron concentration was determined using a colorimetric method (Iron, Randox Laboratories Ltd., UK), whereas serum ferritin and transferrin were measured by immunoturbidimetry (Laboratories Ltd., UK). Quantification of total bilirubin was performed by a colorimetric test (diazotized sulfanilic acid reaction, Roche Diagnostics); circulating levels of glucose and uric acid were determined by routine automated technology (ABX Diagnostics). Serum levels of interleukin-6 (IL-6), interferon- $\gamma$ (IFN- $\gamma$ ), transforming growth factor (TGF- $\beta 1$ ), and vascular endothelial growth factor (VEGF) were measured by ratspecific Quantikine ELISA kits from R\&D Systems (Minneapolis, USA). High-sensitive C-reactive protein (hsCRP) 
was determined by using a rat-specific ELISA kit from Alpha Diagnostics International (San Antonio, USA).

2.4. Detection of Anti-EPO Antibodies. The detection of antiEPO antibodies was carried out by ELISA, according to Urra et al., 1997, using rHuEPO (Recormon, Roche Pharmaceuticals) as antigen and, as secondary antibody, goat anti-rat IgG conjugated with horseradish peroxidase (Sigma; $100 \mathrm{ng} / \mathrm{mL}$ for $1 \mathrm{~h}$, at room temperature) [17]. The substrate tetramethylbenzidine (TMB) (Sigma) was added and the reaction was stopped by the addition of sulphuric acid $1.25 \mathrm{~mol} / \mathrm{L}$. The optical density at $450 \mathrm{~nm}$ (OD450) was determined with an automatic plate reader.

2.5. Gene Expression Analysis. In order to isolate total RNA, $0.2 \mathrm{~g}$ of liver, duodenum, and kidney samples, from each rat, was immersed in RNA later (Ambion, Austin, USA) upon collection and stored at $4^{\circ} \mathrm{C}$, for $24 \mathrm{~h}$; afterwards, samples were frozen at $-80^{\circ} \mathrm{C}$. Subsequently, tissue samples weighing $50 \pm 10 \mathrm{mg}$ were homogenized in a total volume of $1 \mathrm{~mL}$ TRI Reagent using a homogenizer, and total RNA was isolated according to manufacturer instructions (Sigma, Sintra, Portugal). To ensure inactivation of contaminating RNAses, metal objects and glassware were cleaned with detergent, immersed in RNAse-free water ( $0.2 \%$ diethyl pyrocarbonate) for $2 \mathrm{~h}$, and finally heated at $120^{\circ} \mathrm{C}$ for $1 \mathrm{~h}$. RNA integrity (RIN, RNA Integrity Number) was analyzed using 6000 Nano kit, in Agilent 2100 bioanalyzer (Agilent Technologies, Walbronn, Germany), and 2100 expert software, following manufacturer instructions. The yield from isolation was from 0.5 to $1.5 \mu \mathrm{g}$; RIN values were 7.8-9.0 and purity (A260/A280) was 1.8-2.0. The concentrations of the RNA preparations were confirmed with NanoDrop1000 (ThermoScientific, Wilmington, DE, USA). Possible contaminating remnants of genomic DNA were eliminated by treating these preparations with deoxyribonuclease I (amplification grade) prior to RT-qPCR amplification. Reverse transcription and relative quantification of gene expression were performed as previously described [18]. Real-time qPCR reactions were performed for the following genes: $E P O, E P O R$, transferrin receptor 2 (TfR2), hepcidin (Hamp), ferroportin (SLC40A1), Hemojuvelin (HJV), transferrin $(T F)$, hemochromatosis (Hfe), divalent metal transporter 1 (DMT1), transferrin receptor 1 (TfR1), matriptase2 (TMPRSS6), and bone morphogenic protein 6 (BMP6), which were normalized in relation to the expression of betaactin $(A c t b)$ and $18 \mathrm{~S}$ ribosomal subunit (18S), as well as to the mean of the control group. Primer sequences are listed in Table 1. Results were analyzed with SDS 2.1 software (Applied Biosystems, Foster City, CA, USA) and relative quantification was calculated using the $2^{-\Delta \Delta C t}$ method [19]. In liver tissue, we studied the EPO, EPOR, TfR2, Hamp, SLC40A1, HJV, TF, Hfe, $B M P 6$, and TMPRSS6 gene expression; in duodenum tissue the gene expressions of DMT1 and SLC40A1 were studied, and in the kidney we evaluated the expression of EPO gene.

2.6. Data Analysis. For statistical analysis, we used the Statistical Package for Social Sciences (SPSS), version 22.0. Results are presented as mean \pm standard deviation. Multiple
TABLE 1: List of primer sequences (F: forward; R: reverse).

\begin{tabular}{|c|c|}
\hline Gene & Primer sequences \\
\hline \multirow{2}{*}{$E P O$} & F: 5'-AGGGTCACGAAGCCATGAAG-3' \\
\hline & R: $5^{\prime}$-GAT TTC GGC TGT TGC CAG TG-3' \\
\hline \multirow{2}{*}{ EPOR } & F: $5^{\prime}$-GCG ACT TGG ACC CTC TCA TC-3' \\
\hline & R: 5'-AGT TAC CCT TGT GGG TGG TG-3' \\
\hline \multirow{2}{*}{ Hamp } & F: $5^{\prime}$-GAA GGC AAG ATG GCA CTA AGC-3' \\
\hline & R: 5' -CAG AGC CGT AGT CTG TCT CG-3' \\
\hline \multirow{2}{*}{$T f R 2$} & F: $5^{\prime}$-CAA GCT TCG CCC AGA AGG TA-3' \\
\hline & R: 5'-CGT GTA AGG GTC CCC AGT TC-3' \\
\hline \multirow{2}{*}{ SLC40A1 } & F: $5^{\prime}$-CAG GCT TAG GGT CTA CTG CG-3' \\
\hline & R: $5^{\prime}$-CCG AAA GAC CCC AAA GGA CA-3' \\
\hline \multirow{2}{*}{$H J V$} & F: $5^{\prime}$-GCC TAC TTC CAA TCC TGC GT-3' \\
\hline & R: 5'-GGT CAA GAA GAC TCG GGC AT-3' \\
\hline \multirow{2}{*}{$T F$} & F: $5^{\prime}$-GGC ATC AGA CTC CAG CAT CA-3' \\
\hline & R: 5'-GCA GGC CCA TAG GGA TGT T-3' \\
\hline \multirow{2}{*}{ Hfe } & F: $5^{\prime}$-CTG GAT CAG CCT CTC ACT GC-3' \\
\hline & R: $5^{\prime}$-GTC ACC CAT GGT TCC TCC TG-3' \\
\hline \multirow{2}{*}{ DMT1 } & F: $5^{\prime}$-CAA CTC TAC CCT GGC TGT GG-3' \\
\hline & R: 5'-GTC ATG GTG GAG CTC TGT CC-3' \\
\hline \multirow{2}{*}{$T f R 1$} & F: 5'-GCT CGT GGA GAC TAC TTC CG-3' \\
\hline & R: 5'-GCC CCA GAA GAT GTG TCG G-3' \\
\hline \multirow{2}{*}{ TMPRSS6 } & F: $5^{\prime}$-CCG AAT ATG AGG TGG ACC CG-3' \\
\hline & R: $5^{\prime}$-GGT TCA CGT AGC TGT AGC GG-3' \\
\hline \multirow{2}{*}{ BMP6 } & F: 5'-GCT GCC AAC TAT TGT GAC GG-3' \\
\hline & R: 5'-GGT TTG GGG ACG TAC TCG G-3' \\
\hline \multirow{2}{*}{$18 S$} & F: 5'-CCA CTA AAG GGC ATC CTG GG-3' \\
\hline & R: $5^{\prime}$-CAT TGA GAG CAA TGC CAG CC-3' \\
\hline \multirow{2}{*}{$A c t b$} & F: $5^{\prime}$-GAG ATT ACT GCC CTG GCT CC-3' \\
\hline & R: $5^{\prime}$-CGG ACT CAT CGT ACT CCT GC-3' \\
\hline
\end{tabular}

comparisons between groups were performed by one-way ANOVA supplemented with Tukey's HSD post hoc test. For single comparisons, we used the Mann-Whitney $U$ test. Significance was accepted for a $P$ minor than 0.05 .

\section{Results}

The changes in $\mathrm{RBC}$ count, $\mathrm{Hb}$ concentration, hematocrit, and the number of reticulocytes for the three groups are presented in Figure 2. During the 9-week experimental protocol, the $50 \mathrm{IU}$ rHuEPO group, when compared to the control group, showed similar values for RBC count, $\mathrm{Hb}$ concentration, hematocrit, and reticulocytes, though a significant increase in reticulocyte count was observed at $T_{2}$ and $T_{3}$. Concerning the rats treated with $200 \mathrm{IU}$ rHuEPO, in the first 3 weeks, we found a significant increase $(>30 \%$ the basal value) in hemoglobin levels, RBC count, hematocrit, and reticulocyte count, as compared to control and $50 \mathrm{IU}$ rHuEPO groups; after this period, the hemoglobin concentration, hematocrit, and RBC count as well as the number of reticulocytes decreased, reaching significantly lower values at $T_{2}$, as compared to $T_{1}$; this trend towards decreasing values was maintained till the end of the experiment ( 9 weeks). 

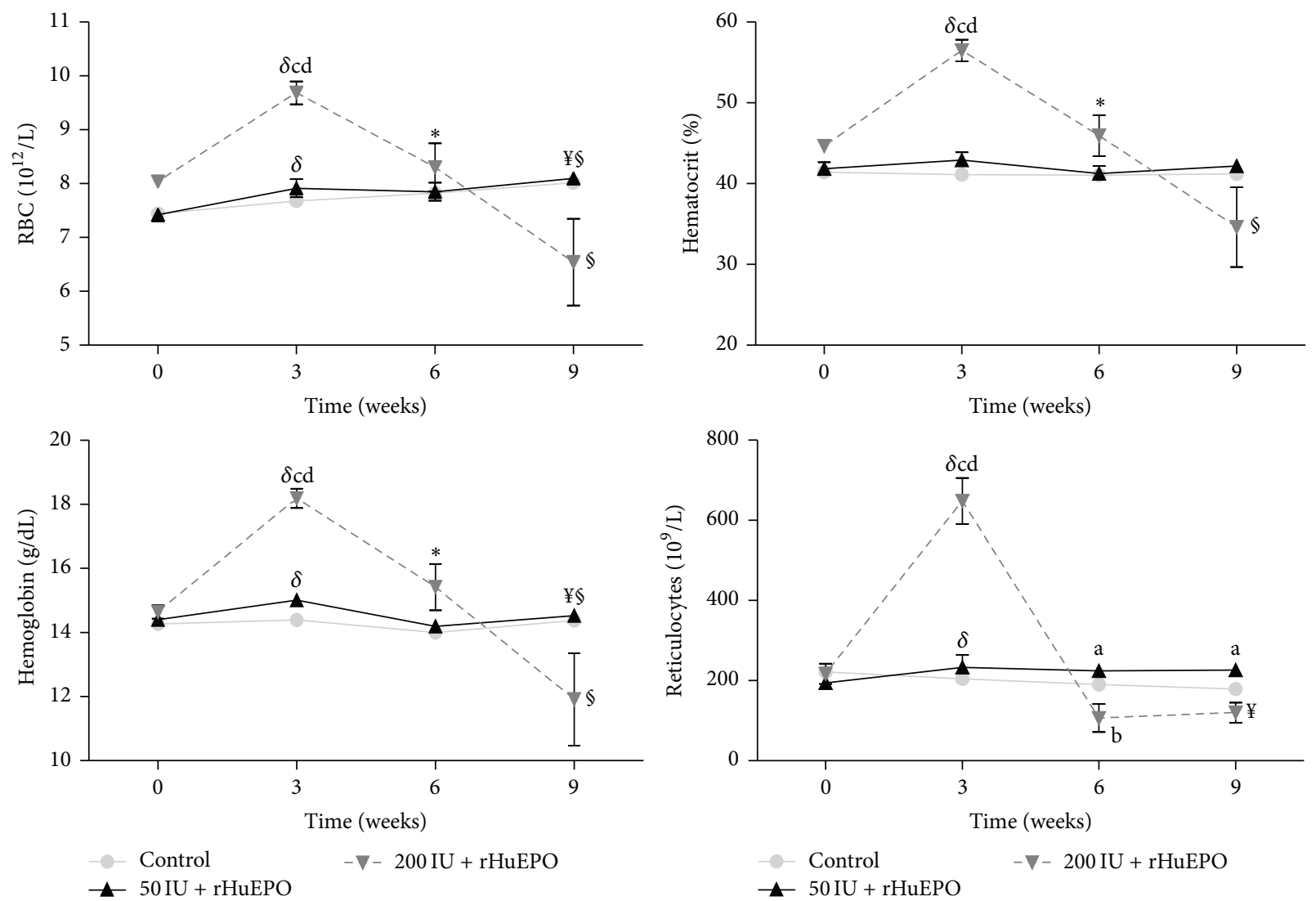

FIGURE 2: Erythrocyte data and reticulocyte count during the follow-up period of 9 weeks under rHuEPO treatment. Results are expressed as mean \pm SD. ${ }^{\mathrm{a}} P<0.05$ versus control; ${ }^{\mathrm{b}} \mathrm{P}<0.05$ versus $50 \mathrm{IU}$ rHuEPO; ${ }^{\mathrm{c}} \mathrm{P}<0.001$ versus control; ${ }^{\mathrm{d}} \mathrm{P}<0.001$ versus $50 \mathrm{IU}$ rHuEPO; ${ }^{\delta} P<0.005 T_{0}$ versus $T_{1} ;{ }^{*} P<0.05 T_{1}$ versus $T_{2} ;{ }^{\S} P<0.05 T_{2}$ versus $T_{3}$.

At the end of the protocol, serum erythropoietin levels were similar among the three groups (Table 2). No changes were observed in glucose, creatinine, urea, uric acid, and bilirubin levels for both rHuEPO groups along the entire protocol, when compared to the control. The inflammatory marker, IL-6, presented a significant decrease in the $200 \mathrm{IU}$ rHuEPO group when compared with the control and $50 \mathrm{IU}$ rHuEPO groups; hsCRP, IFN- $\gamma$, TGF- $\beta 1$, and VEGF showed no significant differences between the three studied groups. Concerning iron metabolism, we found that serum iron was significantly higher for the $200 \mathrm{IU}$ rHuEPO group, when compared with the control and 50 IU rHuEPO groups; no significant differences were found in ferritin and transferrin serum levels between the three studied groups (Table 2).

Serum samples from all animals were also analyzed for anti-rHuEPO antibodies at $T_{1}, T_{2}$, and $T_{3}$; however, only at $T_{3}$ we detected the presence of anti-rHuEPO antibodies in circulation. These were detected in 5 rats under $50 \mathrm{IU}$ rHuEPO treatment, as well as in 5 rats treated with $200 \mathrm{IU}$ rHuEPO (62.5\% for both groups); the antibody titer was fourfold higher in the group under $200 \mathrm{IU}$ rHuEPO; the latter presented a titer of $1: 16$, and the group under the lower rHuEPO dose presented a titer of $1: 4$. Within each rHuEPO group, no other significant differences were found between the rats with or without anti-rHuEPO antibodies.
Bone marrow examination of rats treated with $200 \mathrm{IU}$ rHuEPO showed a proportion of red-cell precursors significantly lower than those without $\mathrm{rHuEPO}$ treatment. The myeloid: erythroid ratio was 2.1:1 for the control group, while for the $200 \mathrm{IU}$ rHuEPO group the ratio was $6.8: 1$; the $50 \mathrm{IU}$ rHuEPO group presented a myeloid: erythroid ratio similar to that found for the control $(2.5: 1)$.

Major changes were observed in the gene expression of iron regulatory proteins and in erythropoietic regulatory proteins in liver tissue (Figure 3), particularly in the $200 \mathrm{IU}$ rHuEPO group. Indeed, the $50 \mathrm{IU}$ rHuEPO group showed significant overexpression of $H J V$ and SLC4OAl genes, as compared to control, while the $200 \mathrm{IU}$ rHuEPO group presented significant overexpression of Hamp, Hfe, HJV, EPOR, SLC40A1, Tf, TfR2, and BMP6 genes, as compared to control and 50 IU rHuEPO group. EPO gene was significantly downregulated in both groups, and TMPRSS6 gene expression was significantly downregulated only in the $200 \mathrm{IU}$ rHuEPO group, as compared to the control and $50 \mathrm{IU}$ rHuEPO groups.

The evaluation of the expression of DMT1 and SLC40A1 genes in duodenum showed that only the $200 \mathrm{IU}$ rHuEPO group presented a significant upregulation for both genes (Figure 4), as compared to the control. Furthermore, as observed in liver, the expression of EPO in kidney tissue 
TABle 2: Hematological and biochemical data at the end of protocol ( 9 weeks).

\begin{tabular}{lccc}
\hline Parameters & \multicolumn{2}{c}{ Groups } \\
& Control & 50 IU rHuEPO & 200 IU rHuEPO \\
\hline EPO $(\mathrm{mIU} / \mathrm{mL})$ & $1.87 \pm 0.25$ & $1.65 \pm 0.23$ & $1.80 \pm 0.21$ \\
Iron $(\mu \mathrm{g} / \mathrm{dL})$ & $183.63 \pm 41.58$ & $188.63 \pm 35.27$ & $255.14 \pm 112.28^{\mathrm{a}, \mathrm{b}}$ \\
Ferritin $(\mathrm{ng} / \mathrm{dL})$ & $165.13 \pm 19.19$ & $168.50 \pm 42.95$ & $162.57 \pm 39.81$ \\
Transferrin $(\mathrm{mg} / \mathrm{mL})$ & $97.75 \pm 8.68$ & $99.38 \pm 6.59$ & $96.14 \pm 9.68$ \\
Glucose $(\mathrm{mg} / \mathrm{dL})$ & $160.88 \pm 29.04$ & $174.62 \pm 20.21$ & $187.71 \pm 37.43$ \\
Creatinine $(\mathrm{mg} / \mathrm{dL})$ & $0.40 \pm 0.05$ & $0.37 \pm 0.03$ & $0.35 \pm 0.06$ \\
Urea $(\mathrm{mg} / \mathrm{dL})$ & $45.10 \pm 1.92$ & $45.05 \pm 3.56$ & $42.74 \pm 5.10$ \\
Uric acid $(\mathrm{mg} / \mathrm{dL})$ & $0.94 \pm 0.46$ & $0.70 \pm 0.13$ & $1.03 \pm 0.52$ \\
Bilirubin $(\mathrm{ng} / \mathrm{mL})$ & $0.043 \pm 0.016$ & $0.054 \pm 0.013$ & $0.064 \pm 0.014$ \\
IL-6 $(\mathrm{pg} / \mathrm{mL})$ & $138.10 \pm 5.34$ & $139.98 \pm 6.12$ & $130.16 \pm 5.06^{\mathrm{a}, \mathrm{b}}$ \\
hsCRP $(\mu \mathrm{g} / \mathrm{mL})$ & $229.31 \pm 24.55$ & $237.49 \pm 28.92$ & $249.46 \pm 33.49$ \\
IFN- $\gamma(\mathrm{pg} / \mathrm{mL})$ & $24.44 \pm 23.07$ & $21.45 \pm 6.80$ & $20.82 \pm 10.13$ \\
TGF- $\beta 1(\mathrm{ng} / \mathrm{mL})$ & $80.21 \pm 4.99$ & $80.03 \pm 17.22$ & $78.10 \pm 5.55$ \\
VEGF $(\mathrm{pg} / \mathrm{mL})$ & $5.36 \pm 4.26$ & $5.84 \pm 3.85$ & $6.04 \pm 3.25$ \\
\hline
\end{tabular}

Results are expressed as mean $\pm \mathrm{SD} .{ }^{\mathrm{a}} \mathrm{P}<0.05$ versus control; ${ }^{\mathrm{b}} \mathrm{P}<0.05$ versus $50 \mathrm{IU}$ rHuEPO. IL-6: interleukin-6; hsCRP: high-sensitive C-reactive protein; IFN- $\gamma$ : interferon- $\gamma$; TGF- $\beta$ : transforming growth factor betal; VEGF: vascular endothelial growth factor.

presented a trend towards downregulation in both rHuEPO groups, when compared to the control (Figure 5).

\section{Discussion}

Antibody-mediated EH/PRCA is a rare pathological complication associated with the use of recombinant human erythropoietins and development of anti-EPO antibodies. However, the use of EPO biosimilars has increased the number of cases in the last years [11,20,21]. Clinically, that condition not only abrogates the effect of the rHuEPO, but may also neutralize endogenous EPO, leading to severe EH and transfusion-dependent anemia.

In this work we developed an animal model of antibodymediated $\mathrm{EH}$, by long-term treatment with a high dose of $\mathrm{rHuEPO}$ (200 IU/Kg bw/week during 9 weeks) in Wistar rats. In order to confirm that we were in fact in the presence of an animal model of this hematological disorder, we assessed the parameters typically used as diagnostic criteria for EH/PRCA, which include normocytic anemia with sudden onset, normocellular bone marrow with a selective reduction in red blood cell precursors beyond proerythroblasts, reticulocytopenia, normal or slightly decreased leucocyte counts, and increased serum iron [22]. We found that the group treated with $200 \mathrm{IU} / \mathrm{Kg}$ bw/week of rHuEPO along 9 weeks fits all these criteria and the majority (65\%) of the rats presented detectable anti-rHuEPO antibodies, suggesting that we achieved an antibody-mediated $\mathrm{EH}$. The group under $50 \mathrm{IU} / \mathrm{Kg}$ bw/week rHuEPO treatment presented only slight changes, as compared to control; however most of the rats $(65 \%)$ presented anti-rHuEPO antibodies at a lower titer (four times less), suggesting that a longer experimental protocol could also lead to the changes associated with $\mathrm{EH}$.

Indeed, Casadevall (2005) reported that the detection of anti-erythropoietin antibodies in circulation is not immediately associated with PRCA [23]. Moreover, no significant changes were observed in hsCRP, IL-6, and IFN- $\gamma$, for both rHuEPO treated groups, showing that no inflammatory changes could interfere with erythropoiesis and iron metabolism.

Our data suggest that the development of EH was due to the antibodies directed to $\mathrm{rHuEPO}$ that inhibited the erythropoietic stimuli of both rHuEPO and endogenous EPO. Indeed, in spite of the normal endogenous EPO levels that were similar to those of the control group, the $200 \mathrm{IU}$ rHuEPO group developed anemia, suggesting that the antirHuEPO antibodies also neutralized the action of endogenous EPO. It has been described that the presence of rHuEPO in circulation may increase severalfold the expression of $E P O R$ [4]. Actually, we found an overexpression of EPOR in the liver of the $200 \mathrm{IU}$ rHuEPO group. The decreased $E P O$ expression observed in kidney and liver tissues, for both rHuEPO groups, seems to be in accordance with a physiological response to the increased circulating levels of rHuEPO, used in the treatment. However, we should not exclude the hypothesis raised by Piron et al. (2001), that this anemia could be due to an inappropriate erythropoietic stimulation or to intrinsic failure of erythroid cells to respond to that stimulus [24].

Anemia usually triggers erythropoiesis by increasing EPO production through the hypoxia-inducible factor (HIF) pathway, by mobilizing iron from the iron storage pool and by increasing iron absorption, in order to face the increased iron needs for erythropoiesis [25]. Considering that, in antibody-mediated $\mathrm{EH}$, the erythropoietic stimuli fail, due to the inhibition of rHuEPO by anti-rHuEPO antibodies, the serum iron should increase, as its absorption and mobilization would be triggered by the anemic condition, and hepcidin should be repressed to favour iron absorption and mobilization. Actually, we found a significant increase in serum iron in the $200 \mathrm{IU}$ rHuEPO group. It is known that increasing serum iron induces hepcidin synthesis by 

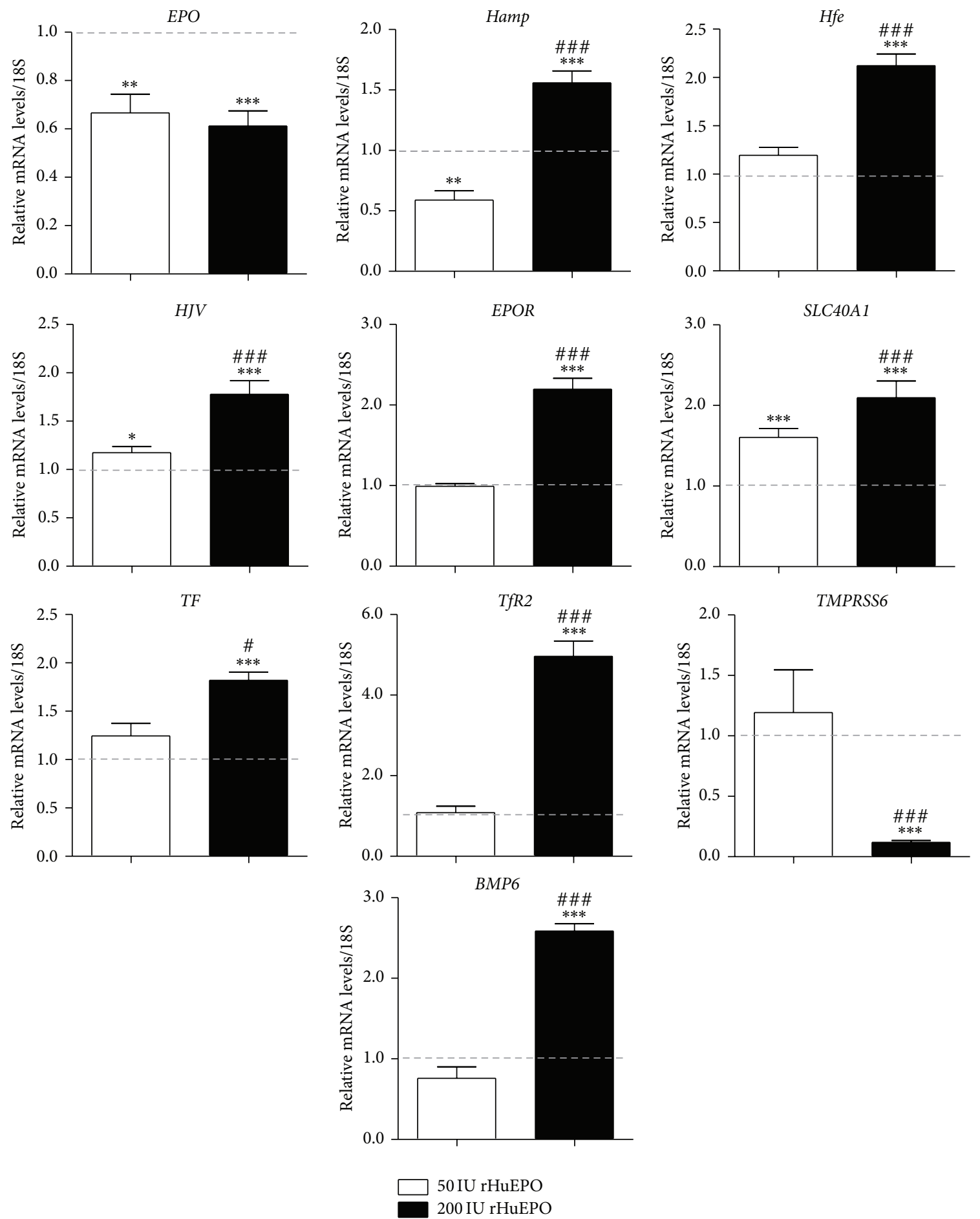

FIGURE 3: Relative mRNA expression of erythropoietin and iron regulatory proteins in the liver, at the end of the protocol ( 9 weeks). 18S rRNA was used as reference gene. Results are expressed as mean $\pm \mathrm{SD} .{ }^{*} P<0.05,{ }^{* *} P<0.01$, and ${ }^{* * *} P<0.001$ versus control group; ${ }^{*} P<0.05$, ${ }^{\# \#} P<0.01$, and ${ }^{\# \#} P<0.001$ versus 50 IU rHuEPO.

a complex pathway. Indeed, hepcidin, encoded by the Hamp gene, is believed to play a key regulatory role in iron absorption. It controls plasma iron concentration and tissue distribution of iron by inhibiting intestinal iron absorption, iron recycling by macrophages, and iron mobilization from stores [26]. Hepcidin acts by inhibiting cellular iron efflux in hepatocytes, enterocytes, and macrophages, through binding to ferroportin, inducing its degradation [27]. Hepatic Hamp expression is regulated by a cohort of proteins, including Hfe, TfR2, HJV, BMP6, matriptase-2, and transferrin [28-30]. 

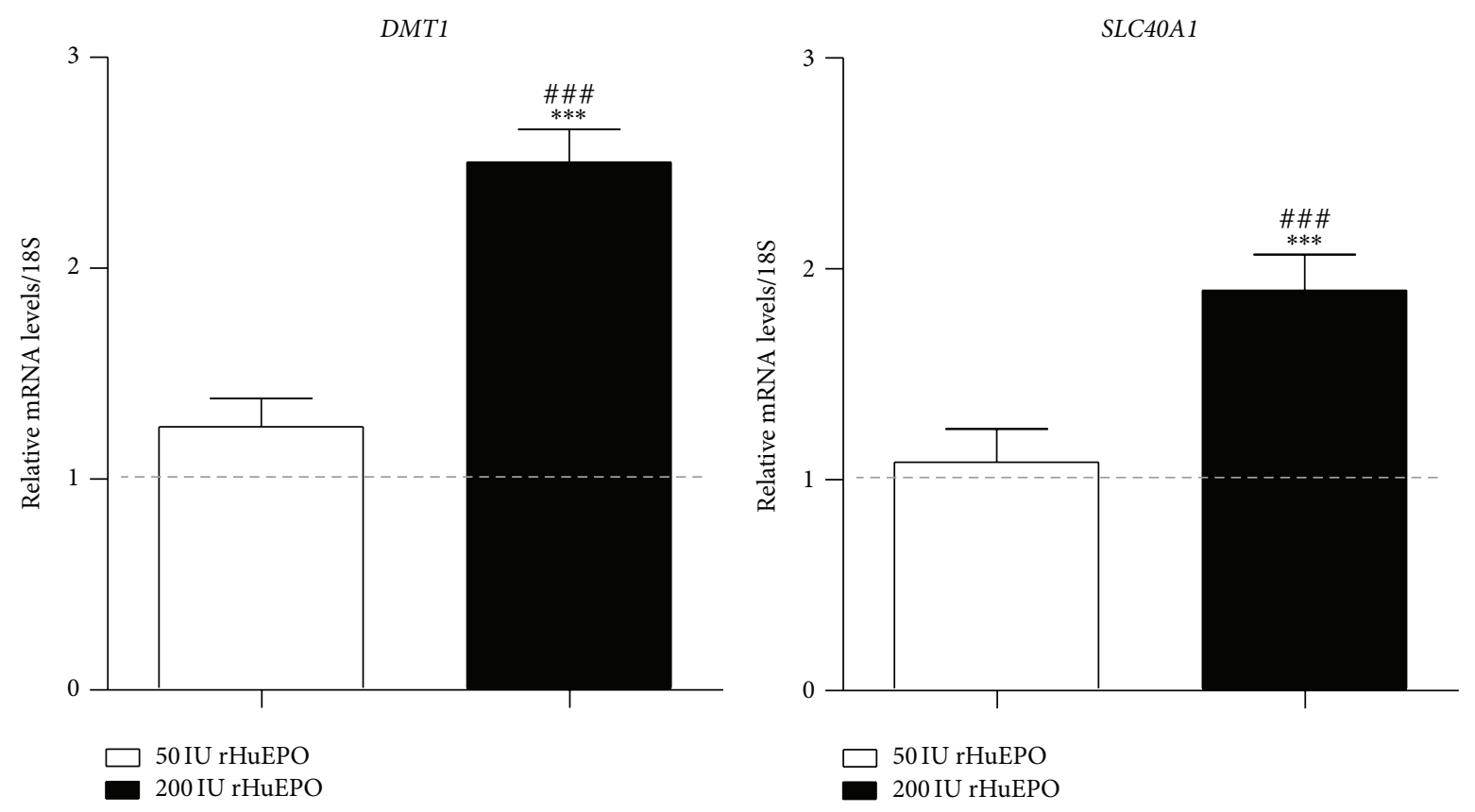

FIGURE 4: Relative mRNA expression of SLC40A1 and DMT1 in the duodenum, at the end of the protocol ( 9 weeks). 18S rRNA was used as reference gene. Results are expressed as mean $\pm \mathrm{SD} .{ }^{* * *} P<0.001$ versus control group, ${ }^{\# \#} P<0.01$, and ${ }^{\# \# \#} P<0.001$ versus 50 IU rHuEPO.

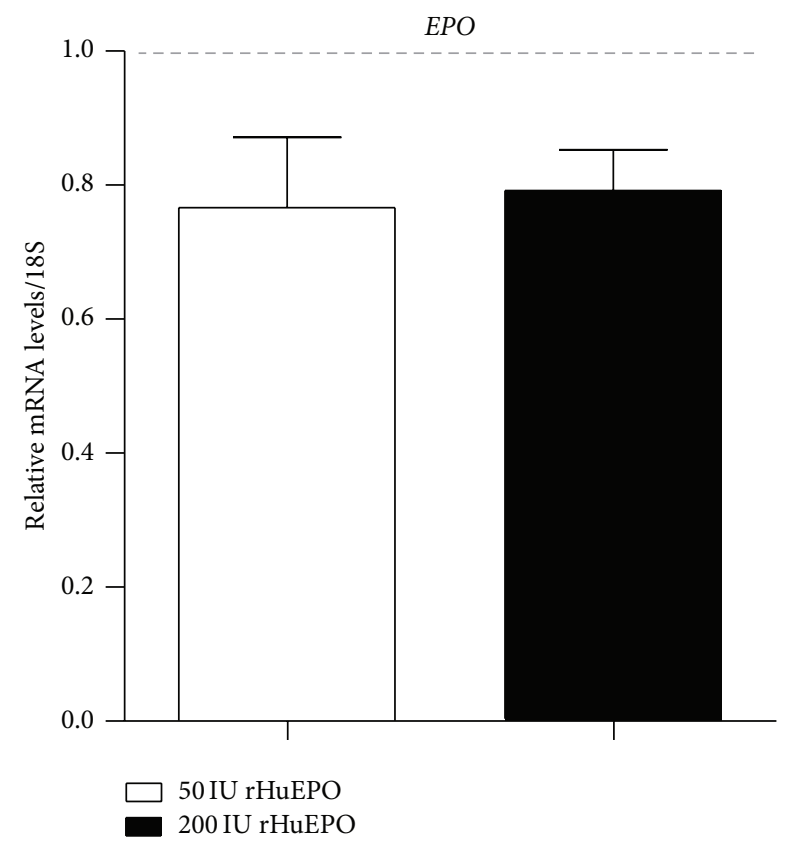

FIGURE 5: Relative mRNA expression of erythropoietin in the kidney, at the end of the protocol (9 weeks). 18S rRNA was used as reference gene. Results are expressed as mean \pm SD.

Studies in both human and animal models indicate that $\mathrm{Hfe}$ and TfR2 are mild inducers of hepcidin expression [28], as compared to HJV and Tmprss6, which are robust modifiers of hepcidin expression [31-33]. TfR2 has been hypothesized to act as a sensor for iron levels in the body because of its largely hepatocyte-specific expression and its ability to mediate cellular iron transport [34]. Although TfR2 is a minor contributor to the uptake of transferrin-bound iron by the liver, experiments with mice have shown that its major role is to modulate the signalling pathway that controls Hamp induction [34]. Hfe has also been implicated in the iron signalling complex that modulates hepcidin transcription by sensing changes in iron levels [35]. Increasing expression of $H J V$ enhances Hamp expression by interacting with BMPs [36] possibly as a coreceptor. Matriptase-2 has been shown to negatively regulate Hamp gene and, therefore, to decrease hepcidin expression and promote iron uptake [37]. It is highly expressed in the liver and participates in a transmembrane signaling pathway triggered by iron deficiency and suppresses hepcidin expression by cleaving membrane-bound hemojuvelin (mHJV) to increase iron absorption [38].

In the liver, diferric transferrin competes with TfR for binding to Hfe, and, when iron is increased, more Hfe is available to bind to TfR2; this complex, TfR2-Hfe, promotes HJV binding to BMP6, increasing hepcidin synthesis $[34,36]$. Indeed, we found that increased serum iron in the $200 \mathrm{IU}$ rHuEPO group was associated with an overexpression of $T f$, $T f R 2, B M P 6, H f e$, and $H J V$ in the liver and, accordingly, with an overexpression of Hamp. Moreover, a downregulation in matriptase mRNA was observed in the liver that might further contribute to the overexpression of hepcidin (Figure 6). In accordance with the overexpression of hepcidin, a reduction in serum iron would be expected, due to the degradation of ferroportin by hepcidin, instead of the increase that we found. It is known that regulation of iron absorption is mediated by signals reflecting oxygen tension in enterocytes, intracellular iron levels, and systemic iron needs. Enterocyte 


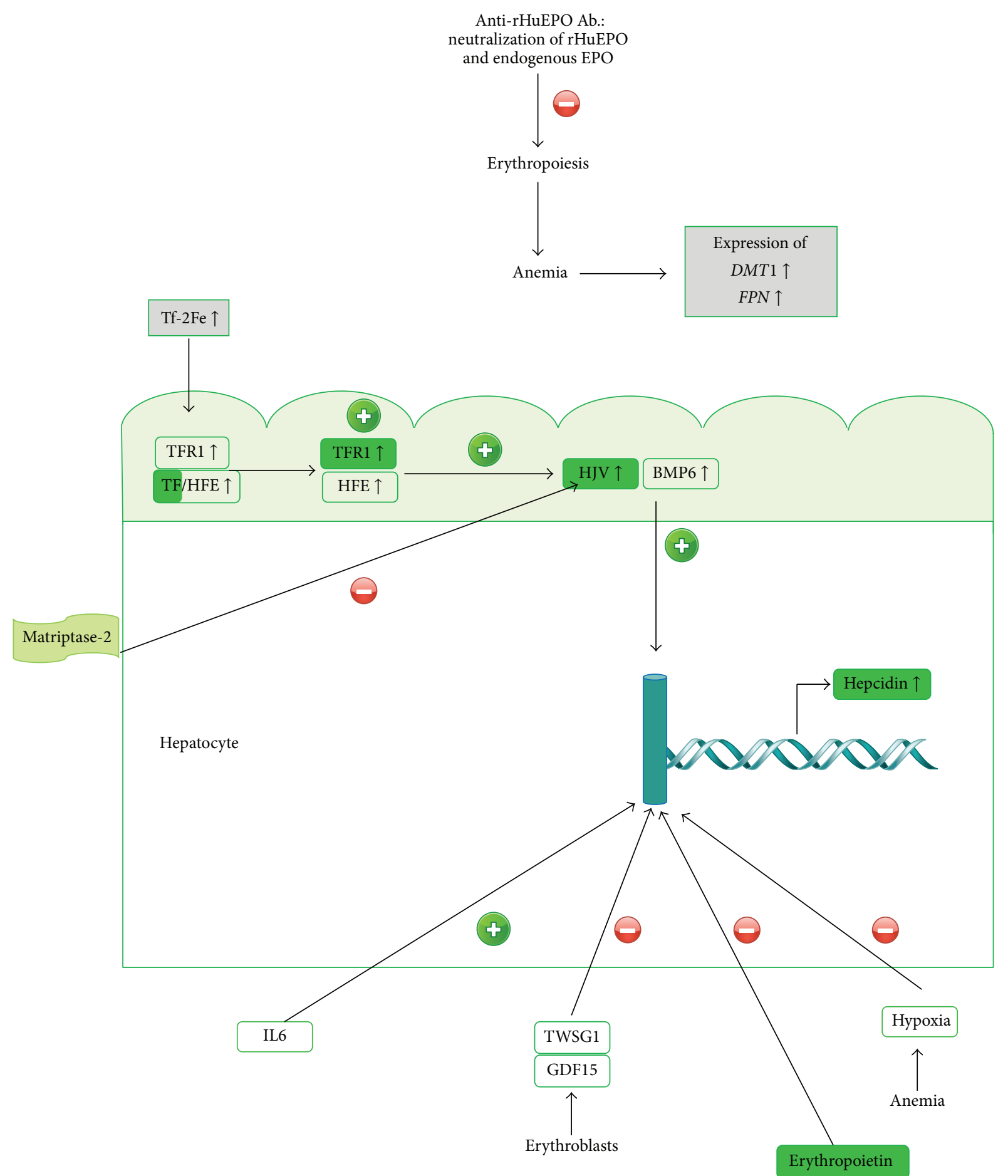

FIGURE 6: Model proposed for erythropoiesis and iron metabolism in erythroid antibody-mediated hypoplasia. Anti-rHuEPO antibodies inhibit both rHuEPO and endogenous EPO leading to anemia that is further aggravated by increased iron that favours hepcidin expression.

oxygen tension regulates iron absorption through its effects on the transcription of HIFs and subsequent changes in transcription of $D M T 1$ [39]. Iron exits the enterocyte through the efflux transporter ferroportin 1 (FPN), the only member of the SLC40 family of transporters and the first reported protein that mediates the exit of iron from cells [40]. Actually, we found an overexpression of DMT1 and ferroportin in the duodenum and liver from the $200 \mathrm{IU}$ rHuEPO group, in response to the anemic state. However, as the overexpression of hepcidin compromises iron absorption and mobilization, the observed increase in serum iron might result mainly from the decreased use of iron for the inhibited erythropoiesis. 
Hypoxia, EPO, as well as twisted gastrulation protein 1 (TWSG1) and growth differentiation factor 15 (GDF15) [41], both produced by erythroblasts, is known to downregulate hepcidin synthesis. Considering the inhibition of erythropoiesis through the anti-rHuEPO antibodies, the production of TWSG1 and GDF15 might be reduced and, therefore, migh be unable to downregulate hepcidin synthesis. We also found that $\mathrm{rHuEPO}$ treatment did not alter renal function and glucose levels and was not associated with an inflammatory process, when compared to the control.

Considering the four functionally hepcidin regulatory pathways described [42-45], erythropoiesis, iron status, oxygen tension, and inflammation, we found that, in our model, erythropoiesis was blunted leading to anemia, iron was increased, and there was no inflammation. It seems, therefore, that the increased iron concentration is the key modulator of hepcidin synthesis in this type of erythroid hypoplasia. In fact, it has been recently reported that the reduction of serum iron by iron chelation therapy promoted an improvement in erythropoiesis in PRCA, though the mechanism whereby this is achieved is still unclear [46].

In conclusion, our data suggest that, in the case of erythroid antibody-mediated hypoplasia/PRCA induced by a high rHuEPO dose (200 IU), as erythropoiesis is blunted through anti-rHuEPO antibodies, iron concentration becomes the key modulator for hepcidin synthesis, which will, probably, contribute to further aggravation of the anemia. These findings might be important to improve new therapeutic strategies against $\mathrm{rHuEPO}$ resistance and/or development of antibody-mediated EH/PRCA in patients under $\mathrm{rHuEPO}$ therapy.

\section{Conflict of Interests}

The authors declare no conflict of interests.

\section{Authors' Contribution}

J. C. Fernandes and P. Garrido have contributed equally to this paper.

\section{Acknowledgments}

This study was supported by Fundação para a Ciência e Tecnologia (FCT: PTDC/SAU-TOX/114253/2009 and Pest/C/SAU/3282/2013) and cofinanced by COMPETE. FCT has also contributed with a postdoctoral Grant attributed to João Fernandes (SFRH/BPD/81968/2011) and Ph.D. degree Grants attributed to Patrícia Garrido (SFRH/BD/61020/2009) and Sandra Ribeiro (SFRH/BD/79875/2011).

\section{References}

[1] E. Moore and R. Bellomo, "Erythropoietin (EPO) in acute kidney injury," Annals of Intensive Care, vol. 1, no. 1, pp. 1-10, 2011.

[2] D. Choi, M. Kim, and J. Park, "Erythropoietin: physico- and biochemical analysis," Journal of Chromatography B: Biomedical Applications, vol. 687, no. 1, pp. 189-199, 1996.
[3] P. Sathyanarayana, A. Dev, J. Fang et al., "EPO receptor circuits for primary erythroblast survival," Blood, vol. 111, no. 11, pp. 5390-5399, 2008.

[4] D. W. Johnson, C. A. Pollock, and I. C. Macdougall, "Erythropoiesis-stimulating agent hyporesponsiveness," Nephrology, vol. 12, no. 4, pp. 321-330, 2007.

[5] N. Casadevall, E. Dupuy, P. Molho-Sabatier, G. Tobelem, B. Varet, and P. Mayeux, "Autoantibodies against erythropoietin in a patient with pure red-cell aplasia," The New England Journal of Medicine, vol. 334, no. 10, pp. 630-633, 1996.

[6] A. Hara, T. Wada, S. Kitajima et al., "Combined pure red cell aplasia and autoimmune hemolytic anemia in systemic lupus erythematosus with anti-erythropoietin autoantibodies," American Journal of Hematology, vol. 83, no. 9, pp. 750-752, 2008.

[7] B. Viron, C.-A. Dupuy, A. Kolta, and N. Casadevall, "Successful re-challenge with darbepoetin in a patient with $\mathrm{rHu}-\mathrm{EPO}$ induced pure red cell aplasia refractory to immunosuppressive drugs," Nephrology Dialysis Transplantation, vol. 23, no. 7, pp. 2416-2418, 2008.

[8] N. Casadevall, "Pure red cell aplasia and anti-erythropoietin antibodies in patients treated with epoetin," Nephrology Dialysis Transplantation, vol. 18, supplement 8, pp. viii37-viii41, 2003.

[9] S.-K. Shin, S. J. Moon, S. K. Ha et al., "Immunogenicity of recombinant human erythropoietin in Korea: a two-year crosssectional study," Biologicals, vol. 40, no. 4, pp. 254-261, 2012.

[10] S. K. Shin, S. P. Pack, J.-G. Oh et al., "Anti-erythropoietin and anti-thrombopoietin antibodies induced after administration of recombinant human erythropoietin," International Immunopharmacology, vol. 11, no. 12, pp. 2237-2241, 2011.

[11] K.-U. Eckardt and N. Casadevall, "Pure red-cell aplasia due to anti-erythropoietin antibodies," Nephrology Dialysis Transplantation, vol. 18, no. 5, pp. 865-869, 2003.

[12] N. Casadevall, J. Nataf, B. Viron et al., "Pure red-cell aplasia and antierythropoietin antibodies in patients treated with recombinant erythropoietin," The New England Journal of Medicine, vol. 346, no. 7, pp. 469-475, 2002.

[13] P. Fisch, R. Handgretinger, and H.-E. Schaefer, "Pure red cell aplasia," British Journal of Haematology, vol. 111, no. 4, pp. 10101022,2000

[14] B. Moulouel, D. Houamel, C. Delaby et al., "Hepcidin regulates intrarenal iron handling at the distal nephron," Kidney International, vol. 84, no. 4, pp. 756-766, 2013.

[15] S. K. Srai, B. Chung, J. Marks et al., "Erythropoietin regulates intestinal iron absorption in a rat model of chronic renal failure," Kidney International, vol. 78, no. 7, pp. 660-667, 2010.

[16] J. B. Wish, "Assessing iron status: beyond serum ferritin and transferrin saturation," Clinical Journal of the American Society of Nephrology: CJASN, vol. 1, pp. S4-S8, 2006.

[17] J. M. Urra, M. de la Torre, R. Alcazar, and R. Peces, "Rapid method for detection of anti-recombinant human erythropoietin antibodies as a new form of erythropoietin resistance," Clinical Chemistry, vol. 43, no. 5, pp. 848-849, 1997.

[18] M. Teixeira, P. Rodrigues-Santos, P. Garrido et al., "Cardiac antiapoptotic and proproliferative effect of recombinant human erythropoietin in a moderate stage of chronic renal failure in the rat," Journal of Pharmacy and Bioallied Sciences, vol. 4, no. 1, pp. 76-83, 2012.

[19] K. J. Livak and T. D. Schmittgen, "Analysis of relative gene expression data using real-time quantitative PCR and the 2$\Delta \Delta$ CT method," Methods, vol. 25, no. 4, pp. 402-408, 2001. 
[20] J. M. McKoy, R. E. Stonecash, D. Cournoyer et al., "Epoetinassociated pure red cell aplasia: past, present, and future considerations," Transfusion, vol. 48, no. 8, pp. 1754-1762, 2008.

[21] A. V. Kharagjitsingh, J. C. Korevaar, J. P. Vandenbroucke et al., "Incidence of recombinant erythropoietin (EPO) hyporesponse, EPO-associated antibodies, and pure red cell aplasia in dialysis patients," Kidney International, vol. 68, no. 3, pp. 12151222, 2005.

[22] S.-H. Bi, L.-T. Cheng, W. Chen, and T. Wang, "Characteristic changes in anti-erythropoietin antibodies in a peritoneal dialysis patient who developed pure red cell aplasia," Hong Kong Journal of Nephrology, vol. 8, no. 2, pp. 71-74, 2006.

[23] N. Casadevall, "What is antibody-mediated pure red cell aplasia (PRCA)?" Nephrology Dialysis Transplantation, vol. 20, supplement 4, pp. iv3-iv8, 2005.

[24] M. Piron, M. Loo, A. Gothot, F. Tassin, G. Fillet, and Y. Beguin, "Cessation of intensive treatment with recombinant human erythropoietin is followed by secondary anemia," Blood, vol. 97, no. 2, pp. 442-448, 2001.

[25] V. H. Haase, "Hypoxic regulation of erythropoiesis and iron metabolism," The American Journal of Physiology —Renal Physiology, vol. 299, no. 1, pp. F1-F13, 2010.

[26] T. Ganz, "Hepcidin and iron regulation, 10 years later," Blood, vol. 117, no. 17, pp. 4425-4433, 2011.

[27] G. C. Preza, R. Pinon, T. Ganz, and E. Nemeth, "Cellular catabolism of the iron-regulatory peptide hormone hepcidin," PLoS ONE, vol. 8, no. 3, Article ID e58934, 2013.

[28] A.-S. Zhang, "Control of systemic iron homeostasis by the hemojuvelin-hepcidin axis," Advances in Nutrition, vol. 1, no. 1, pp. 38-45, 2010.

[29] K. E. Finberg, "Unraveling mechanisms regulating systemic iron homeostasis," Hematology / the Education Program of the American Society of Hematology, vol. 2011, no. 1, pp. 532-537, 2011.

[30] E. Canavesi, C. Alfieri, S. Pelusi, and L. Valenti, "Hepcidin and HFE protein: Iron metabolism as a target for the anemia of chronic kidney disease," World Journal of Nephrology, vol. 1, no. 6, pp. 166-176, 2012.

[31] Y. Cui, Q. Wu, and Y. Zhou, "Iron-refractory iron deficiency anemia: new molecular mechanisms," Kidney International, vol. 76, no. 11, pp. 1137-1141, 2009.

[32] T. Ganz and E. Nemeth, "The hepcidin-ferroportin system as a therapeutic target in anemias and iron overload disorders," Hematology/the Education Program of the American Society of Hematology, vol. 2011, pp. 538-542, 2011.

[33] A. Nai, A. Pagani, L. Silvestri et al., "TMPRSS6 rs855791 modulates hepcidin transcription in vitro and serum hepcidin levels in normal individuals," Blood, vol. 118, no. 16, pp. 44594462, 2011.

[34] E. L. Mackenzie, K. Iwasaki, and Y. Tsuji, "Intracellular iron transport and storage: from molecular mechanisms to health implications," Antioxidants \& Redox Signaling, vol. 10, no. 6, pp. 997-1030, 2008.

[35] S. Pelucchi, R. Mariani, P. Trombini et al., "Expression of hepcidin and other iron-related genes in type 3 hemochromatosis due to a novel mutation in transferrin receptor-2," Haematologica, vol. 94, no. 2, pp. 276-279, 2009.

[36] A.-S. Zhang, F. Yang, J. Wang, H. Tsukamoto, and C. A. Enns, "Hemojuvelin-neogenin interaction is required for bone morphogenic protein-4-induced hepcidin expression," The Journal of Biological Chemistry, vol. 284, no. 34, pp. 22580-22589, 2009.
[37] L. Silvestri, A. Pagani, A. Nai, I. de Domenico, J. Kaplan, and C. Camaschella, "The serine protease matriptase-2 (TMPRSS6) inhibits hepcidin activation by cleaving membrane hemojuvelin," Cell Metabolism, vol. 8, no. 6, pp. 502-511, 2008.

[38] A. Piperno, R. Mariani, P. Trombini, and D. Girelli, "Hepcidin modulation in human diseases: from research to clinic," World Journal of Gastroenterology, vol. 15, no. 5, pp. 538-551, 2009.

[39] R. E. Fleming and P. Ponka, "Iron overload in human disease," The New England Journal of Medicine, vol. 366, no. 4, pp. 348359, 2012.

[40] A. T. McKie, P. Marciani, A. Rolfs et al., "A novel duodenal iron-regulated transporter, IREG1, implicated in the basolateral transfer of iron to the circulation," Molecular Cell, vol. 5, no. 2, pp. 299-309, 2000.

[41] T. Tanno, P. Porayette, O. Sripichai et al., "Identification of TWSG1 as a second novel erythroid regulator of hepcidin expression in murine and human cells," Blood, vol. 114, no. 1, pp. 181-186, 2009.

[42] E. Fung and E. Nemeth, "Manipulation of the hepcidin pathway for therapeutic purposes," Haematologica, vol. 98, no. 11, pp. 1667-1676, 2013.

[43] Q. Liu, O. Davidoff, K. Niss, and V. H. Haase, "Hypoxiainducible factor regulates hepcidin via erythropoietin-induced erythropoiesis," Journal of Clinical Investigation, vol. 122, no. 12, pp. 4635-4644, 2012.

[44] N. K. N. Shanmugam and B. J. Cherayil, "Serum-induced upregulation of hepcidin expression involves the bone morphogenetic protein signaling pathway," Biochemical and Biophysical Research Communications, vol. 441, no. 2, pp. 383-386, 2013.

[45] Y. Hamada and M. Fukagawa, "Is hepcidin the star player in iron metabolism in chronic kidney disease," Kidney International, vol. 75, no. 9, pp. 873-874, 2009.

[46] M. Kojima, S. Machida, A. Sato et al., "Deferasirox treatment improved hematopoiesis and led to complete remission in a patient with pure red cell aplasia," International Journal of Hematology, vol. 98, no. 6, pp. 719-722, 2013. 


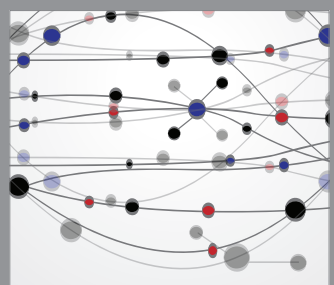

The Scientific World Journal
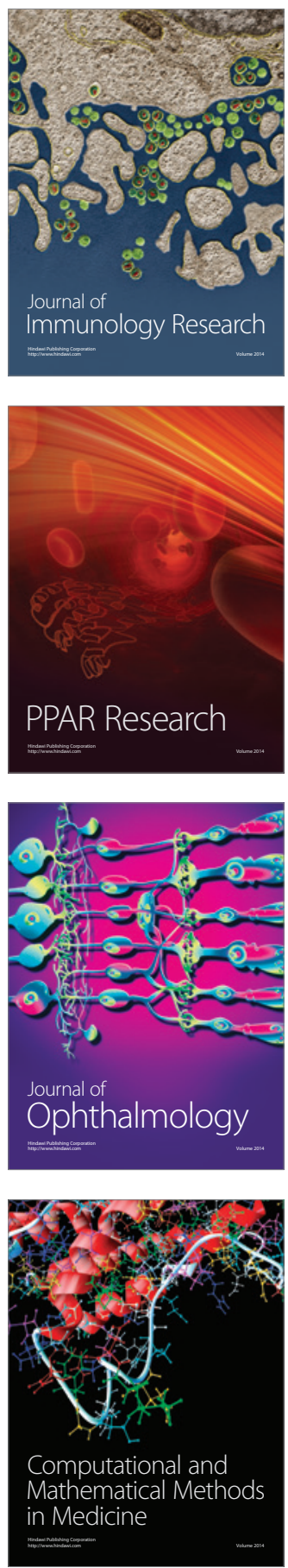

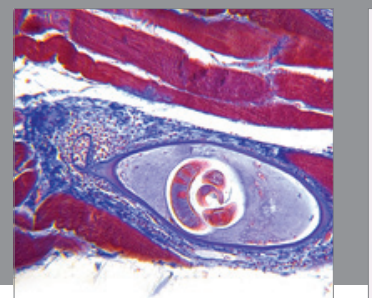

Gastroenterology

Research and Practice
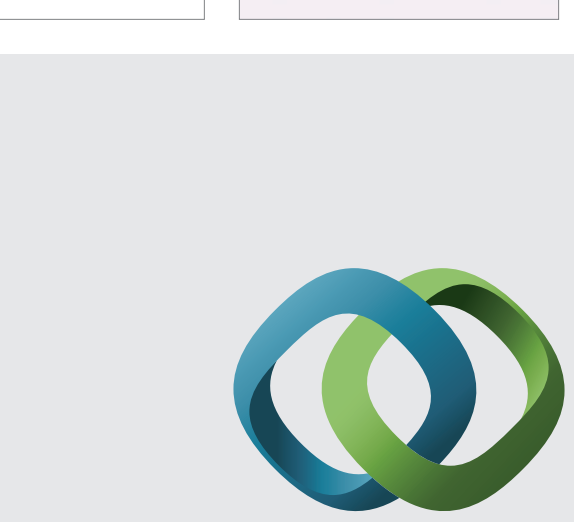

\section{Hindawi}

Submit your manuscripts at

http://www.hindawi.com
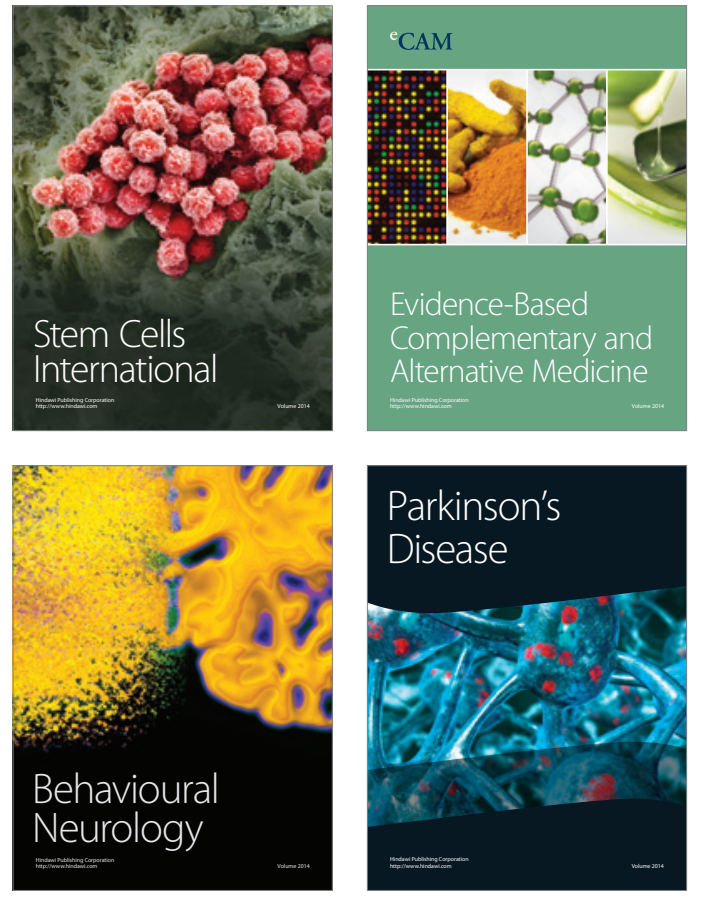
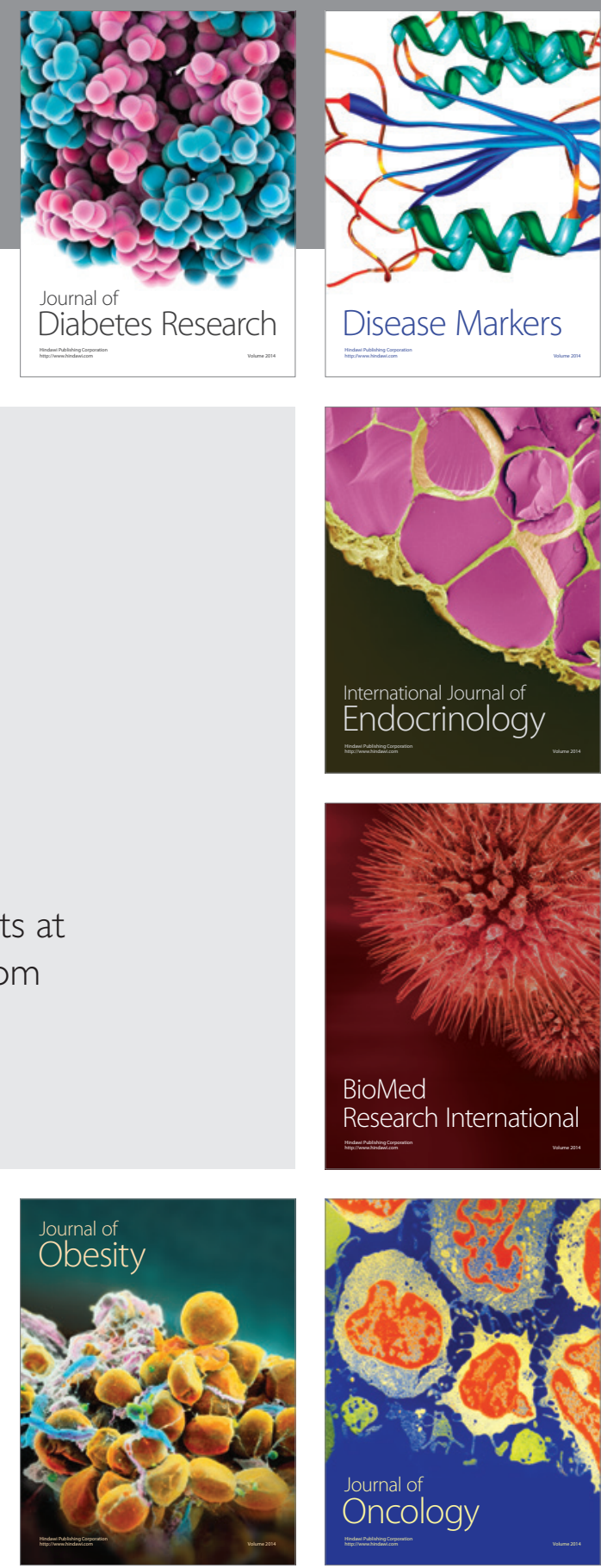

Disease Markers
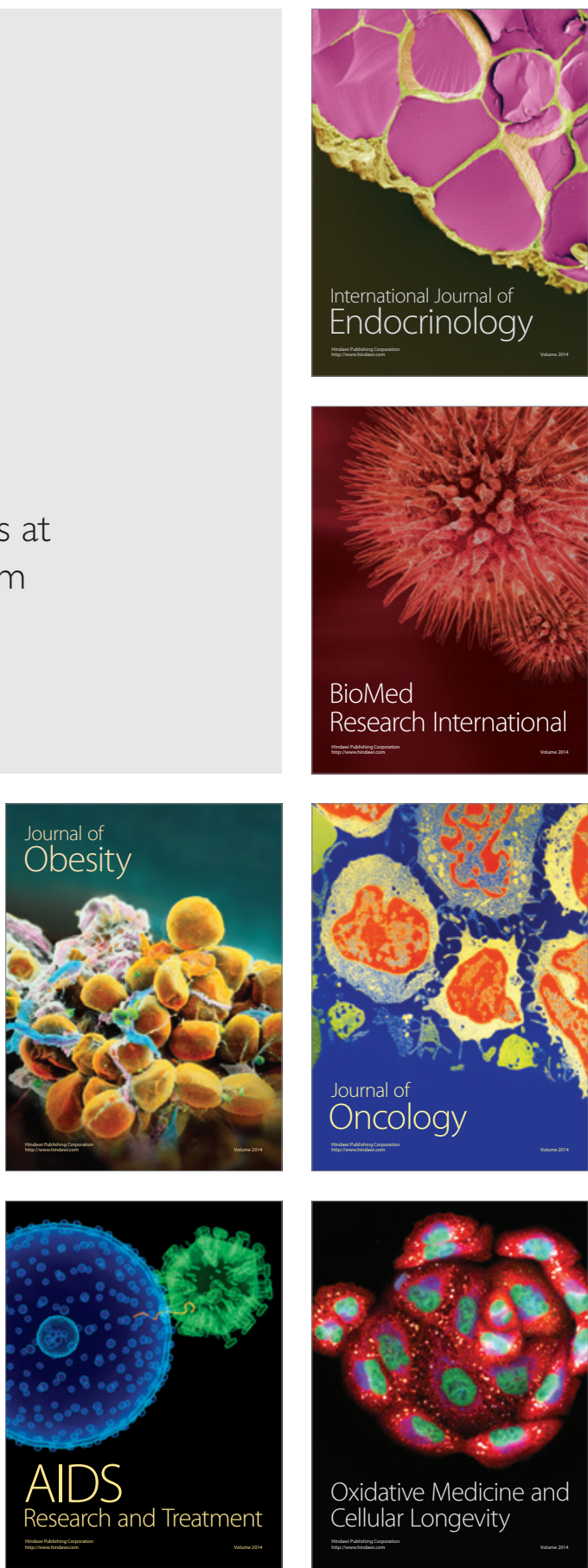